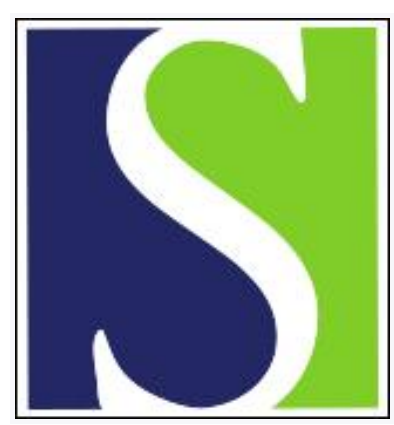

Scand J Work Environ Health 1987;13(4):271-274

https://doi.org/10.5271/sjweh.2051

Issue date: Aug 1987

Clinical assessment of suspected damage from hand-held vibrating tools.

by Ekenvall L

Affiliation: Clinic of Occupational Medicine, Karolinska sjukhuset, Stockholm, Sweden.

This article in PubMed: www.ncbi.nlm.nih.gov/pubmed/3324307

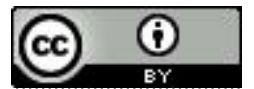




\title{
Clinical assessment of suspected damage from hand-held vibrating tools
}

\author{
by Lena Ekenvall, $\mathrm{MD}, \mathrm{PhD}^{1}$
}

\begin{abstract}
EKENVALL L. Clinical assessment of suspected damage from hand-held vibrating tools. Scand $J$ Work Environ Health 13 (1987) 271-274. The case history is still the cornerstone in the clinical assessment of suspected vibration injury. Objective tests to verify the symptoms are needed for legal reasons in insurance cases and for research purposes. The minimum requirement of a test used to obtain objective signs of Raynaud's phenomenon is that patients with vibration-induced white finger be evaluated along with symptom-free, but vibration-exposed, subjects for reference. The measurement of systolic blood pressure in the finger after local finger and general body cooling is a test that has been evaluated in this way, as has restitution of finger temperature after local cooling and ischemia combined with general body heating. If neurological symptoms are present, electroneurographic examination is essential since carpal tunnel syndrome, a treatable condition, is common in vibration-exposed patients. Measurements of vibration and temperature thresholds are complementary examinations. The so-called vibrogram may be a method with which to obtain objective neurological signs of vibration injury, but the test needs further evaluation. Until more is known of the pathophysiological mechanisms behind the disease, the patient's description of his symptoms, combined with a detailed exposure history, will remain essential for a diagnosis of vibration injury - irrespective of the results of the tests used.
\end{abstract}

Key terms: cold provocation test, diagnosis, electroneurography, nerve injury, nicotine, Raynaud's phenomenon, sensibility, symptom scale, vibration syndrome.

Long-term use of vibrating tools often leads to the development of vibration syndrome. The most wellknown of the symptoms included in the syndrome is Raynaud's phenomenon (38), ie, attacks of white fingers induced by cold [called vibration-induced white finger (VWF) when caused by work with hand-held vibrating tools]. Hand-arm vibration also affects the nerves of the hands $(50,51,52)$. Decreased sensitivity to vibration (53), temperature (29), or touch $(11,58)$ has been found in vibration-exposed workers. The frequency of carpal tunnel syndrome or other neuropathy $(1,9,19,34,61)$ is also increased among vibrationexposed workers. Hand-arm vibration may affect muscles $(20,21,32,51)$ and contribute to osteoarthrosis (23). Symptoms from the central nervous system have been discussed as being caused by work with vibrating tools $(36,37)$, but most researchers deny any causative connection between vibration exposure and such symptoms (8). An increased hearing loss seems to exist among vibration-exposed workers with Raynaud's phenomenon when these workers are compared with symptom-free workers from the same occupations with similar exposure times $(31,49)$.

This paper deals with the clinical assessment of Raynaud's phenomenon and neurological symptoms in workers exposed to hand-arm vibration.

1 Clinic of Occupational Medicine, Karolinska Sjukhuset, Stockholm, Sweden.

Reprint requests to: Dr L Ekenvall, Clinic of Occupational Medicine, Karolinska sjukhuset, S-104 01 Stockholm, Sweden.

\section{Evaluation of a patient with suspected vibration injury}

\section{Case history}

Case history is the cornerstone of the clinical assessment of suspected vibration injury. Questionnaires can be used in screening surveys of exposed groups, but they cannot replace direct contact between the physician and the patient. A detailed exposure history and the patient's description of symptoms are essential. The information on exposure to vibrating tools must include the number of years in exposed work, type(s) of tools used, and, if no objective registration can be obtained, the patient's estimation of daily exposure time.

The medical history should be recorded with special emphasis on causes other than hand-arm vibration for the existing symptoms $(10,12)$. The physical examination should include a neurological examination (sensibility and motor function of the hands), palpation of the radial artery (due to the possibility of thoracic outlet syndrome) and ulnar artery (Allen's test). The patient's smoking habits should be noted.

\section{Vasospastic disease}

Any cold-induced symptoms should be graded according to an internationally known symptom scale. The Taylor-Pelmear symptom scale (55) - now appearing in a revised version (22) - is the best known of these assessment schemes, but other scales are sometimes used $(46,54)$. Those including symptoms from the 
central nervous system cannot be used internationally, since such symptoms are not recognized by all researchers as belonging to the vibration syndrome (54). The existence of different symptom scales is unfortunate, since no test for Raynaud's phenomenon is ideal or universally accepted. One internationally accepted and consistently used symptom scale would greatly facilitate the comparison of epidemiologic studies, dose-effect studies, and studies on different diagnostic procedures.

Cold provocation tests are often used to obtain objective signs of Raynaud's phenomenon. Time-consuming, drastic, and, for the patient, very uncomfortable cooling procedures are needed to provoke an attack in the laboratory $(28,46)$. Therefore researchers have tried to find tests that, without provoking an attack, can demonstrate a changed reactivity to cold $(27,28,33,41,43)$. Men working with vibrating tools, irrespective of whether they have VWF or not, seem to have an increased reactivity to cold in comparison to unexposed healthy referents $(12,24)$. Thus any test used to diagnose VWF must be evaluated with vibration-exposed but healthy persons as reference.

The measurement of systolic blood pressure in the finger after general body and local finger cooling (13, $42,44,45)$ is the test preferred in our laboratory. It gives few falsely positive results in exposed (or unexposed) referents, but about $25 \%$ falsely negative results in patients with a reliable history of VWF (15, 57). The test results might be influenced by the patient's smoking habits in that nonsmokers have a higher frequency of normal test results (14).

The measurement of temperature restitution after a hand has been cooled during ischemia and general body heating is a test that, on a group basis, demonstrates a difference between VWF patients and healthy referents $(35,60)$. A similar test, but without body heating, separates VWF patients and vibration-exposed referents on a group basis (24). Other cold provocation tests have also been used, eg, the cold pressor test (43), the nail compression test (27), and the measurement of finger blood pressure after local cooling, general heating, and the oral administration of alcohol (4).

Other techniques used have been angiography or fluorescein angiography to visualize spastic or organic lesions in finger arteries. Plethysmography, flow measurement with Doppler ultrasound or the laser-Doppler technique can be used to study blood flow in the fingers. None of these techniques has been systematically evaluated in VWF.

As yet, no test can separate VWF from primary Raynaud's disease on an individual level. A person with long-term exposure to vibrating tools, who has developed attacks of white fingers, must be considered as having VWF if no other cause for the symptoms can be demonstrated. VWF can be safely excluded if the symptoms started before the vibration exposure. Agate (2) described cases of white fingers developing in patients who had stopped working with vibrating tools, but recent studies have consistently shown an amelioration of vasospastic symptoms after the cessation of work with vibrating tools $(18,48)$. Thus symptoms starting more than a short time after the cessation of exposure have probably not been induced by vibration.

\section{Neurological symptoms}

Neurological symptoms, mainly in the form of paresthesias in the hands and arms, are even more common in vibration-exposed patients than in unexposed referents $(6,25)$. Paresthesias directly after the use of a vibrating tool are common. Sleep-disturbing paresthesias nightly are typical for carpal tunnel syndrome and common in cases of vibration syndrome. Loss in manipulative skill may also occur (5) and must be separated from sensibility disturbances caused by vasospastic reaction in the cold. A separate scale for the classification of neurological symptoms in the handarm vibration syndrome has now been devised (7).

Since carpal tunnel syndrome is common in vibration-exposed patients $(3,9)$, electroneurographic and electromyographic examinations are necessary for all patients with symptoms consistent with this syndrome. Since the patients often cannot localize the symptoms to median innervated areas only, electroneurography must not be restricted to typical cases.

The vibrogram, ie, the measurement of vibration sensitivity in the finger pulp at different vibration frequencies, has lately been shown to be a sensitive technique to demonstrate early carpal tunnel syndrome (39, 40). The technique has been used for vibration-exposed patients (26) but needs further evaluation in symptomfree vibration-exposed workers before it can be recommended for routine clinical use. The measurement of temporary vibration threshold shift after acute vibration exposure separates patients with symptoms from healthy referents on a group basis better than the determination of permanent vibration thresholds (37). Measurements of temperature thresholds give many pathological results for vibration-exposed patients with neurological symptoms $(16,29,30)$ and therefore indicate that damage to small myelinated and unmyelinated nerve fibers is common in the vibration syndrome. Further evaluation of this technique is also necessary. Temperature and vibration thresholds (possibly after acute vibration exposure) are comparatively easy to measure quantitatively and might be used for screening exposed groups, even outside the hospital, to detect sensory disturbances early. Vibration thresholds are, however, dependent on skin temperature (59). Skin temperature is lower in VWF patients than in healthy referents even without any induced cold stimulus (17) and thus must be controlled. Moreover, the thresholds are changed by vibration exposure, and any testing must be performed with a standardized latency period since the last work with exposure to vibration. 


\section{Treatment of vibration syndrome}

In the case of the appearance of the vibration syndrome, vibration exposure should be stopped or minimized since there is evidence that vasospastic symptoms improve or disappear in many cases after the cessation of exposure. Many years seem to be needed before an amelioration of the symptoms can be expected however $(18,47)$. Since VWF attacks are induced by cold, it is probably rational to advise the patient to avoid occupations involving exposure to cold. There is some evidence that nicotine might aggravate vasospastic symptoms $(14,56)$, and the avoidance of nicotine is recommended.

Apart from carpal tunnel syndrome, which can often be successfully treated with an operation, there exists no treatment for the neuropathy that appears with the vibration syndrome. There are indications that neurological symptoms do not easily disappear after the cessation of vibration exposure $(25,48)$. If this possibility can be verified, patients with signs of neuropathy must avoid vibrating tools at an early stage.

\section{Suggestions for the "minimum examination" necessary for suspected vibration syndrome}

As stated in the preceding text, the case history is the cornerstone of the diagnosis of suspected vibration syndrome. Detailed exposure data, the patient's description of symptoms, and a physical examination to exclude other possible causes for the symptoms are essential. Circulatory and neurological symptoms should be classified according to symptom scales, preferably internationally accepted ones. Objective tests to verify Raynaud's phenomenon are necessary for legal reasons in insurance cases and for research purposes.

If neurological symptoms are present, an electroneurographic examination (measurement of motor and sensory conduction velocities and sensory amplitudes in the median and ulnar nerves on both sides) is essential since carpal tunnel syndrome, a treatable condition, is common in vibration-exposed groups. The measurement of sensory thresholds might be used as complementary examinations. Until more is known of the pathophysiological mechanism behind the symptoms of the vibration syndrome, the patient's description of symptoms, combined with a detailed exposure history, will remain essential for the diagnosis irrespective of the results of the tests used. A patient who has a typical history of Raynaud's phenomenon and/or paresthesias and has been exposed to hand-arm vibration daily for many years, when no other reason for the symptoms can be found, must be considered as having vibration syndrome.

\section{References}

1. Abbruzzese M, Loeb C, Ratto S, Sacco G. A comparative electrophysiological and histological study of sensory conduction velocity and Meissner corpuscles of the median nerve in pneumatic tool workers. Eur Neurol 16 (1977) 106-114.

2. Agate JN. An outbreak of cases of Raynaud's phenomenon of occupational origin. Br J Ind Med 6 (1949) $144-163$.

3. Ahlborg G, Voog L, de Laval J, Holm Glad J. Vibrationsexponering och distal kompression av nervus medianus [Vibration exposure and distal compression of the median nerve ("carpal tunnel syndrome")]. Läkartidningen 79 (1982) 4905-4908. (English abstract).

4. Arneklo-Nobin B, Norgren L, Sjöberg T. The differentiation of Raynaud's phenomenon by measuring skin temperature and digital arterial pressure and their responses to local cooling and to vasodilatation. In: Arneklo-Nobin B, ed. The white cold hand. University of Lund, Lund (Sweden) 1983. (Bulletin no 37).

5. Banister PA, Smith FV. Vibration-induced white fingers and manipulative dexterity. Br J Ind Med 29 (1972) $264-267$.

6. Bovenzi M, Petronio L, Di Marino F. Epidemiological survey of shipyard workers exposed to hand-arm vibration. Int Arch Occup Environ Health 46 (1980) $251-266$.

7. Brammer AJ, Taylor W, Lundborg G. Sensorineural stages of the hand-arm vibration syndrome. Scand $\mathbf{J}$ Work Environ Health 13 (1987) 279-283.

8. Bruyn GW. Vibration-induced central dysautonomia: Fact or fiction? J Low Freq Noise Vib 1 (1983): special issue, $100-107$.

9. Chatterjee DS, Barwick DD, Petrie A. Exploratory electromyography in the study of vibration-induced white finger in rock drillers. Br J Ind Med 39 (1982) 89-97.

10. Coffman JD, Davies WT. Vasospastic diseases: A review. Prog Cardiovasc Dis 18 (1975) 123-146.

11. Corlett EN. A new aesthesiometer for investigating vibration white finger (VWF). Ergonomics 24 (1981) 49-54.

12. Ekenvall L, Lindblad LE. Köldprovokationstest vid utredning av traumatisk vasospastisk sjukdom [Cold provocation test in traumatic vasospastic disease]. Opusc Med 24 (1979) 141-143. (English abstract).

13. Ekenvall L, Lindblad LE. Digital blood pressure after local cooling as a diagnostic tool in traumatic vasospastic disease. $\mathrm{Br} \mathbf{J}$ Ind Med 39 (1982) 388-391.

14. Ekenvall L, Lindblad LE. Vibrationsutlösta Raynaudfenomen och nikotinkonsumtion - en preliminär rapport [Vibration-induced white finger and nicotine - A preliminary report]. Opuse Med 30 (1985) 28-31. (English abstract).

15. Ekenvall L, Lindblad LE. Vibration white finger and digital systolic pressure during cooling. $\mathrm{Br} \mathrm{J}$ Ind Med 43 (1986) 280-283.

16. Ekenvall L, Nilsson, BY, Gustavsson P. Temperature and vibration thresholds in vibration syndrome. $\mathrm{Br} \mathrm{J}$ Ind Med 43 (1986) 825-829.

17. Futatsuka M, Pyykkö I, Färkkilä M, Korhonen O, Starck JP. Blood pressure, flow, and peripheral resistance of digital arteries in vibration syndrome. $\mathrm{Br} \mathrm{J}$ Ind Med 40 (1983) 343-441.

18. Futatsuka M, Ueno T, Sakurai T. Follow up study of vibration induced white finger in chain saw operators. Br J Ind Med 42 (1985) 267-271.

19. Färkkilä M, Aatola S, Starck J, Pyykkö I, Korhonen O. Vibration-induced neuropathy among forestry workers. Acta Neurol Scand 71 (1985) $221-225$.

20. Färkkilä M, Pyykkö I, Korhonen O, Starck J. Hand grip forces during chain saw operation and vibration white finger in lumberjacks. Br J Ind Med 36 (1979) 336-341. 
21. Färkkilä M, Pyykkö I, Korhonen O, Starck J. Vibration-induced decrease in the muscle force in lumberjacks. Eur J Appl Physiol Occup Physiol 43 (1980) 1-9.

22. Gemne G, Pyykkö I, Taylor W, Pelmear PL. The Stockholm Workshop scale for the classification of coldinduced Raynaud's phenomenon in the hand-arm vibration syndrome (revision of the Taylor-Pelmear scale). Scand J Work Environ Health 13 (1987) 275-278.

23. Gemne G, Saraste $\mathbf{H}$. Bone and joint pathology in workers using hand-held vibrating tools: An overview. Scand J Work Environ Health 13 (1987) 290-300.

24. Hack M, Boillat M-A, Schweizer C, Lob M. Assessment of vibration induced white finger: Reliability and validixy of two tests. Br J Ind Med 43 (1986) 284-287.

25. Härkönen $H$, Riihimäki H, Tola S, Mattsson T, Pekkarinen M, Zitting A, Husman K. Symptoms of vibration syndrome and radiographic findings in the wrists of lumberjacks. Br J Ind Med 41 (1984) 133-136.

26. Hagberg M, Johansson R, Löfgren F, Zetterlund B. Domningar och känselbortfall $i$ handen hos vibrationsskadade patienter - en hudreceptorskada? [Paresthesias and sensory disturbances in vibration syndrome A damage of cutaneous receptors?]. In: Arbetarskydsstyrelsen. Sammanfattningar från 32:a Nordiska Yrkeshygieniska Mötet. Stockholm 1983, pp 57-58.

27. Harada N, Matsumoto T. Validity of various function tests performed in Japan as a screening test for vibration syndrome. Int Arch Occup Environ Health 54 (1984) $283-293$.

28. Hellstrom B, Myhre K. A comparison of some methods of diagnosing Raynaud phenomena of occupational origin. $\mathrm{Br} \mathrm{J}$ Ind Med 28 (1971) 272-279.

29. Hirosawa I. Original construction of thermo-esthesiometer and its application to vibration disease. Int Arch Occup Environ Health 52 (1983) 209-214

30. Hirosawa I, Watanabe S, Fukuchi Y, Nishiyama K, Hosokawa M. Availability of temperature sense indices for diagnosis of vibration disease. Int Arch Occup Environ Health 52 (1983) 215-222.

31. Iki M, Kurumatani N, Hirata K, Moriyama T. An association between Raynaud's phenomenon and hearing loss in forestry workers. Am Ind Hyg Assoc J 46 (1985) $509-513$.

32. Iwata $\mathrm{H}$. Effects of rock drills on operators: Part 3. Joint and muscle pain, and deformity of bone and joint. Ind Health 6 (1968) 47-58.

33. Jepson RP. The effects of vascular occlusion and local cooling on finger skin blood flow. Clin Sci 13 (1954) $259-265$.

34. Juntunen J, Matikainen E, Seppäläinen AM, Laine A. Peripheral neuropathy and vibration syndrome: A clinical and neurophysiological study of 103 patients. Int Arch Occup Environ Health 52 (1983) 17-24.

35. Juul C, Nielsen SL. Locally induced digital vasospasm detected by delayed rewarming in Raynaud's phenomenon of occupational origin. $\mathrm{Br} \mathrm{J}$ Ind Med 38 (1981) $87-90$.

36. Klimkova-Deutschova E. Neurologische Aspekte der Vibrationskrankheit. Int Arch Gewerbepathol Gewerbehyg 22 (1966) 297-305.

37. Lidström I-M, Hagelthorn $G$, Bjerker N. Vibration perception in persons not previously exposed to local vibration and in vibration exposed workers. In: Brammer AJ, Taylor W, ed. Vibration effects on the hand and arm in industry. John Wiley \& Sons, New York, NY 1982, pp 59-61.

38. Loriga G. Il lavoro con i martelli pneumatici. Boll Inspett Lav 2 (1911) 35.

39. Lundborg G, Sollerman C, Stenström AK. Digital vibrogram - A new diagnostic tool for sensory testing. In: American Society for Surgery of the Hand. 40th annual meeting. Las Vegas, NV 1985, pp 26, 28.

40. Lundborg G, Sollerman C, Strömberg T, Pyykkö I,
Rosén B. A new principle for assessing vibrotactile sense in vibration-induced neuropathy. Scand J Work Environ Health 13 (1987) 375-379.

41. Marshall J, Poole EW, Reynard WA. Raynaud's phenomenon due to vibrating tools - Neurological observations. Lancet 266 (1954) 1151.

42. Nielsen SL, Lassen NA. Measurement of digital blood pressure after local cooling. J Appl Physiol 43 (1977) 907-910.

43. Okada A, Yamashita T, Ideda T. Screening test for Raynaud's phenomenon of occupational origin. Am Ind Hyg Assoc J 33 (1972) 476-482.

44. Olsen N, Nielsen SL. Diagnosis of Raynaud's phenomenon in quarrymen's traumatic vasospastic disease. Scand J Work Environ Health 5 (1979) 249-256.

45. Olsen N, Nielsen SL, Voss $P$. Cold response of digital arteries in chain saw operators. Br J Ind Med 38 (1981) $82-88$.

46. Pyykkö I. The prevalence and symptoms of traumatic vasospastic disease among lumberjacks in Finland: A field study. Work Environ Health 11 (1974) 118-131.

47. Pyykkö I, Korhonen OS, Färkkilä MA, Starck JP, Aatola SA. A longitudinal study of the vibration syndrome in Finnish forestry workers. In: Brammer AJ, Taylor W, ed. Vibration effects on the hand and arm in industry. John Wiley \& Sons, New York, NY 1982, pp 157-167.

48. Pyykkö I, Sairanen E, Korhonen O, Färkkilä M, Hyvärinen $\mathrm{J}$. A decrease in the prevalence and severity of vibration induced white fingers among lumberjacks in Finland. Scand J Work Environ Health 4 (1978) 246254.

49. Pyykkö I, Starck J, Färkkilä M, Hoikkala M, Korhonen $\mathrm{O}$, Nurminen M. Hand-arm vibration in the aetiology of hearing loss in lumberjacks. Br J Ind Med 38 (1981) $281-289$.

50. Rothstein T. Report of the physical findings in eight stonecutters from the limestone region of Indiana. Bull US Bur Labor Stat 236 (1918): series 19, 67-96.

51. Sakurai T. Vibration effects on hand-arm-system: Part 1. Observation of electromyogram. Ind Health 15 (1977) $47-58$.

52. Seppäläinen AM. Peripheral neuropathy in forest workers: A field study. Work Environ Health 9 (1972) 106 111.

53. Starck J, Färkkilä M, Aatola S, Pyykkö I, Korhonen $O$. Vibration syndrome and vibration in pedestal grinding. Br J Ind Med 40 (1983) 426-433.

54. Taylor W. Occupational disability arising from the vibration syndrome. Low Freq Noise Vib 1 (1983): special issue, $1-5$.

55. Taylor W, Pelmear PL, ed. Vibration white finger in industry. Academic Press, London 1975, p xxi.

56. Theriault G, De Guire L, Gingras S, Laroche G. Raynaud's phenomenon in forestry workers in Quebec. Can Med Assoc J 126 (1982) 1404-1408.

57. Thulesius O, Brubakk A, Berlin E. Response of digital blood pressure to cold provocation in cases with Raynaud phenomena. Angiology 32 (1981) 113-118.

58. Verberk MM, Salle HJA, Kempers O. Vibratory and tactile sense of the fingers after working with sanders. Int Arch Occup Environ Health 56 (1985) 217-223.

59. Weitz J. Vibratory sensitivity as a function of skin temperature. J Exp Psychol 28 (1941) 21-36.

60. Welsh CL. Digital rewarming time in the assessment of vibration-induced white finger. Scand J Work Environ Health 12 (1986) 249-250.

61. Wieslander G, Ekenvall L, Göthe C-J. Vibration induced neurological damage. In: Andelkovic T, ed. International symposium on the protection of workers against vibration. Organization Committee of the Institute for Occupational Safety and Health Documentation "Edvard Kardelj,” Niś (Jugoslavia) 1982, pp 67-70. 